\title{
Oil, gas industry of Saudi Arabia
}

\author{
(C) Shaalan Mohamed Abdo Hamud, and Raisa A. Akhmedyanova** \\ Department of Technology of Synthetic Rubber (TSR). Kazan National Research Technological \\ University. K. Marxa, 68. Kazan, Tatarstan Republic. Russia. \\ Phone: +7 (917) 291-09-63. E-mail: achra108@rambler.ru
}

\begin{abstract}
*Supervising author; ${ }^{+}$Corresponding author Keywords: Saudi Arabia, crude oil, oil industry, Saudi Aramco, oil companies.
\end{abstract}

\begin{abstract}
The review of the oil and gas industry in Saudi Arabia is Conducted. Data on oil and gas reserves, consumption, and exports are provided. Saudi Arabia is one of the largest non-FTI producers in the Russian Federation among the non-FTI exporters (OPEC). BL agodarya mirovym za pasam not FTI, one of the most important ones in the world, but the one with the most inquisitive in the field of energy from rasli, Saudi Arabia, is the largest exporter of oil. The data on oil reserves of the largest fields, including the largest in the world of the terikovoye non-oil field of Gavar are presented. Saudi Arabia occupies the fifth place in the world in the field of natural gas passes, with a volume of 294 trillion cubic feet, and the third place in the field of natural gas passes in the Far East. Saudi Arabia they EET de nine EXT morning not preparatively for waste water treatment, of which four PR andlegal Saudi Aramco and the OS the rest of the floor joint PR Adbrite with to foreign companies.

The largest oil and gas companies represented in Saudil Arawia are named, in particular: Saudi Aramco, Saudi Shell, Saudi Exxon Mobil, Saudi Chevron, Total, Eni, Sinopec, Sumitomo. It is shown that Saudi Ar amco is a non-state oil company of Saudi Arabia, the largest in the world in terms of oil production and oil reserves. The company also controls natural gas production in the country. Saudi Aramco is a national non-oil company Of the Saudi Aravia, which is responsible for non-oil and gas operations throughout the Kingdom. Recently, the main goal is to use unconventional gas sources, namely shale gas production. Currently, the company Saudi Aramco has more than 16 drilling rigs for the extraction of shale gas. By the end of 2020, the company is expected to extract 3 billion cubic feet of natural gas per day.
\end{abstract}

\section{References}

[1] Barack Obama. Kazakhstan the International Business Magazine. 2009. No.5. P.29.

[2] G.V. Vygon. The problem of optimal resource allocation. RZB: Commodity Market. 2011. No.4. P.7-9. (russian)

[3] R.Kh. Muslyumov. Oil recovery: past, present, future (production optimization, oil recovery maximization): a tutorial. Kazan: "Fen". 2014.750p. (russian)

[4] Secret wealth. Vedomosti, No.238, December 18, 2016.

[5] URL: http://www.mining-enc.ru/s/saudovskaya-araviya(дата обращения: 02.04.2019)

[6] URL: https://ru.wikipedia.org/wiki/Гавар_(месторождение)(датаобращения:25.011.2018)

[7] Alsharhan, Abdulrahman S. and Kendall, G.St.C. Christopher. Precambrian to Jurassic Rocks of Arabian Gulf and Adjacent Areas: Their Facies, Depositional Setting, and Hydrocarbon Habitat. Bulletin of the American Association of Petroleum Geologists. 2006. Vol.70. P.8.

[8] C.G. Gaddy, B.W. Ickes. Russian economy through 2020: the challenge of managing rent addiction, in: M. Lipman, N. Petrov (Eds.). Russia in 2020: Scenarios for the Future. Carnegie Endowment for International Peace, Washington D.C. 2011. P.165-186.

[9] A. Kudrin, E. Gurvich. Novoi modeli rosta dlya rossiskoi ekonomiki. Vopr. Ekon. 2014. Vol.12. P.4-32.

[10] J. Cooper. Russian Military Expenditure: Data, Analysis and Issues, FOI. Defence Analysis. Stockholm. 2013.

[11] M.L. O'Sullivan. Windfall: How the New Energy Abundance Upends Global Politics and Strengthens America's Power. Simon \& Schuster, New York. 2017.

[12] J. Henderson, J.B. Fattouh. Russia and OPEC: Uneasy Partners, Oxford Energy Studies, Energy Comment, 2016, URL:https://www.oxfordenergy.org/wpcms/wp.../ Russia-and-OPEC-Uneasy- 
Partners.pdf, Accessed date: 19 January 2019.

[13] R.F. Aguilera, M. Radetzki. M. The Price of Oil, CUP, Cambridge, 2016.

[14] R. McNally. Crude Volatility: the History and the Future of Boom and Bust Oil Prices. Columbia University Press, New York. 2017.

[15] Oil Change International, The Sky's the Limit: Why the Paris Climate Goals Require. September, 2016.

[16] D.H. Claes. Politics of Oil-Producer Cooperation. Westview Press, Boulder, CO. 2001.

[17] URL: http://priceofoil.org/content/uploads/2016/09/OCI_the_skys_limit_2016_FINAL_2.pdf Accessed date: 18 January 2019.

[18] K. Bond. 2020 Vision: Why You Should See Peak Fossil Fuels Coming, Carbon Tracker Initiative, London, URL: https://www.carbontracker.org/reports/2020-2018

[19] UNCTAD, Investment trends monitor, 2019. 21 January.

[20] IEA, World Energy Outlook 2018, IEA, Paris, 2018.

[21] BP 2018, Energy Outlook 2018, BP, London. URL: https://www.bp.com/content/dam/bp/en/corporate/pdf/energy-economics/energy-outlook/bpenergy-outlook-2018.pdf, Accessed date: 19 January 2019.

[22] ExxonMobil, Outlook for Energy: A View to 2040, Exxon Mobil, Irving, 2018,

[23] URL: Https://corporate.exxonmobil.com/en/energy/energy-outlook, Accessed date: 19 January 2019.

[24] S. Hedlund, S. Putin's. Energy Agenda: the Contradictions of Russia's Resource Wealth. Lynne Reinner Publishers, London. 2014.

[25] Sky Shell. Meeting the Goals of the Paris Agreement, Shell International B.V., The Hague, 2018. URL: https://www.shell.com/energy-and-innovation/the-energy-future/ cenarios/ shellscenario-sky.html Accessed date: 19 January 2019.

[26] L.-C. Sim. The Rise and Fall of Privatization in the Russian Oil Industry. Palgrave Macmillan, Basingstoke. 2008.

[27] S. Hedlund, S. Putin's. Energy Agenda: the Contradictions of Russia's Resource Wealth. Lynne Reinner Publishers, London. 2014.

[28] Oil Change International, Greenpeace, Forecasting Failure, Why Investors Should Treat Oil Company Energy Forecasts with Caution, Oil Change International, Washington D.C., 2017. URL: http://priceofoil.org/forecasting-failure-/13.03.2017

[29] D. Trenin. What is Russia up to in the Middle East? Polity, Cambridge. 2017.

[30] Oil Change International, Institute for Energy Economics and Financial Analysis, off Track: How the International Energy Agency Guides towards Fossil Fuel

[31] Dependence and Climate Change, Oil Change International, Washington D.C., 2018. URL: http://priceofoil.org/2018/04/04/off-track-the-iea-and-climate-change/, Accessed date: 19 January 2019.

[32] B.K. Sovacool. How long will it take? Conceptualizing the temporal dynamics of energy transitions, Energy Res. Soc. Sci. 13 (2016) 202-215. URL: https://doi.org/10. 1016/j.erss.2015.12.020.

[33] S. Dale, B. Fattouh. Peak Oil Demand and Long-Run Oil Prices, Energy Insight No. 25, Oxford Institute for Energy Studies, Oxford, 2018._URL:https://www.oxfordenergy. org/publications/peak-oil-demand-long-run-oil-prices/, Accessed date: 17 January 2019.

[34] B. Fattouh, R. Poudineh, R. West. The Rise of Renewables and Energy Transition: what Adaptation Strategy for Oil Companies and Oil-Exporting Countries? OIES Paper: MAP vol. 19, Oxford Institute for Energy Studies, Oxford. 2018.

[35] https://www.oxfordenergy.org/publications/rise-renewables-energy-transition-adaptation-strategy-oilcompanies-oil-exporting-countries/ Accessed date: 17 January 2019.

[36] IEA, World Energy Statistics 2018, IEA, Paris, URL: http://data.iea.org/payment/ products/118world-energy-statistics-2018-edition.aspx 2018, 19 January 2019.

[37] D. Buhr, R. Frankenberger. Emerging varieties of incorporated capitalism. Theoretical considerations and empirical evidence. Bus. Polit. 2014. 393-427. URL: https://doi.org/10.1515/bap-2013-002016.2014.

[38] C. Miller. Putinomics. Power and Money in Resurgent Russia, North Carolina University Press, Chapel Hill, 2018.

[39] M. Bradshaw, R. Connolly. Bullets and barrels: the geostrategic significance of Russia's oil and gas exports. Bull. At. Sci. 2016. Vol.72. P.156-164.

[40] S.A. Akhmetov, and other Oil and gas complex of Russia and the world. State and 
developmentprospects. Neftegaz.RU. 2020. Vol.6. P.64-70. (russian)

[41] Bahrain is betting on 80 billion barrels of oil to help clear its budget deficit, 8 may 2018 [Electronic resource]: - URL: https://www.cnbc.com/2018/05/08/bahrain-discovery-of-80-billion-barrels-ofoil.html (Дата обращения: 26.02.2020).

[42] OPEC Annual Statistical Bulletin 2019. 54th edition - 132 p. [Electronic resource]: URL: https://asb.opec.org (Дата обращения: 22.02.2020). 